\title{
Analisis Gaya Belajar Terhadap Hasil Belajar Pendidikan Jasmani Murid SD Inpres No. 33 Sumpang Binangae Kab. Barru
}

\section{Analysis of Learning Styles on Outcomes of Students in Physical Education at SD Inpres No.33 Sumpang Binangae in Barru District}

\author{
Ihsan Abbas \\ Universitas Negeri Makassar \\ Jln. Wijaya Kusuma Raya No.14 \\ Email: ihsan.abbas90@gmail.com
}

\begin{abstract}
ABSTRAK
Tujuan penelitian ini adalah untuk mengetahui Apakah gaya belajar berhubungan dengan hasil belajar pendidikan jasmani murid SD Inpres No.33 Sumpang Binangae di Kabupaten Barru, Apakah sama atau tidak peluang munculnya masing-masing gaya pada murid di SD Inpres No.33 Sumpang Binangae Kabupaten Barru. Penelitian ini menggunakan pendekatan kuatitatif jenis exploratif atau survei dengan teknik pengumpulan data melalui angket, wawancara dan dokumentasi hasil belajar dalam bentuk nilai rapor. Sedangkan teknik analisis data menggunakan analisis deskriptif dan analisis non-parametri (Countingency Coefficient dan Chi-Square). Hasil penelitian menunjukkan bahwa ada hubungan gaya belajar dengan hasil belajar pendidikan jasmani murid SD Inpres No. 33 Sumpang Binangae Kab. Barru; serta peluang munculnya masing-masing gaya belajar tidak sama, khususnya pada murid di SD Inpres No. 33 Sumpang Binangae Kab. Barru
\end{abstract}

\section{Kata Kunci: Gaya Belajar, Hasil Belajar, Pendidikan Jasmani}

\begin{abstract}
The purpose of this study was to determine whether the learning style is related to the physical education learning outcomes of students of SD Inpres No.33 Sumpang Binangae in Barru Regency, whether or not the chances of the emergence of each style in students at SD Inpres No. This research uses a quantitative explorative or survey type approach with data collection techniques through questionnaires, interviews and documentation of learning outcomes in the form of report cards. While the data analysis technique uses descriptive analysis and nonparametric analysis (Countingency Coefficient and Chi-Square). The results showed that there was a relationship between learning styles and physical education learning outcomes of SD Inpres No. students. 33 Sumpang Binangae Kab. Barru; and opportunities for the emergence of different learning styles, especially for students at SD Inpres No. 33 Sumpang Binangae Kab. Barru
\end{abstract}

Keywords: Learning Styles, Learning Outcomes, Physical Education 


\section{PENDAHULUAN}

Setiap individu (murid) adalah mahluk yang unik, mereka berbeda satu dengan yang lainnya (Nazarudin et al 2020). Secara umum ada dua faktor yang menyebabkan terjadinya perbedaan tersebut, yakni faktor warisan keturunan dan faktor pengaruh lingkungan (Sadri, 2020), (Keliat, P., Karo-Karo, A. A. P., \& Muhammad Syaleh, 2020). Dalam realitanya mungkin pada satu individu faktor keturunan lebih dominan sedangkan pada individu lainnya pengaruh faktor lingkungan lebih dominan. Perbedaan tersebut dapat dikembalikan kepada interaksi antar kedua faktor tersebut.

Berpijak dari perbedaan dan faktor yang menyebabkannya, maka kiranya dapat menepis paradigma yang selama ini berkemabang dalam dunia pendidikan kita selama ini, asumsi yang mengatakan bahwa dengan mengajar bahan yang sama, metode yang sama, serta cara penilaian yang sama kepada semua murid dianggap akan menghasilkan hasil yang sama pula adalah hal yang kurang tepat (Devi Catur Winata, Muhammad Fahmi, \& Andi Nur Abady, 2020), sebab meskipun semua diperlakukan sama namun harus diingat bahwa yang melakukan belajar adalah murid-murid itu sendiri, sedang kepribadian, abilitas, emosiaonal dan minat dari masing-masing murid berbeda. Dengan demikian, pembelajaran yang lebih menghargai perbedaan setia murid akan lebih mengembangkan murid sesuai dengan kemampuan dan potensi yang dimilikinya tanpa harus dibandingkan dengan yang lainnya. Maka dari itu melalui penelitian ini, peneliti ingin membuktikan bahwa keunikan setiap murid dalam hal belajar (gaya belajar) memiliki hubungan yang sangat erat dalam hasil belajar pendidikan jasmani dan apakah sama atau tidak peluang munculnya masingmasing gaya belajar, khususnya pada murid di SD Inpres No.33 Sumpang Binangae Kab. Barru.

\section{METODE PENELITIAN}

Penelitian ini menggunaka Total sampling (Sugiyono. 2012) dengan kata lain semua populasi dijadikan sebagai sampel atau sering disebut sampel jenuh yaitu seluruh siswa kelas V SD Inpres Sumpang Binangae Kabupaten Barru yang berjumlah 57 orang.

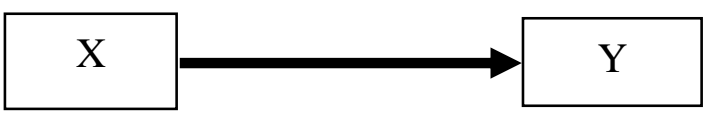

Gambar 1. Desain Penelitian

Teknik analisis data yang digunakan adalah analisis deskriptif dan analisis nonparametri (Sukardi. 2012). Dengan 
Workout From Home Sebagai Aktivitas Mahasiswa Menjaga Kebugaran Jasmani

(Studi Fenomenologi Aktivitas Mahasiswa Ilkor UMBY dalam Menjaga Imunitas Menghadapi Pandemi COVID-19)

menggunakan teknik pengumpulan data Instrumen angket, wawancara dan dokumentasi hasil belajar pendidikan jasmani.

\section{HASIL DAN PEMBAHASAN}

Gambaran data gaya belajar murid SD Inpres No.33 Sumpang Binangae Kab. Barru dapat dilihat pada tabel dibawah ini:

Tabel 1. Distribusi frekuensi gaya belajar murid SD Inpres No.33 Sumpang Binangae Kab. Barru.

\begin{tabular}{ccc}
\hline GAYA BELAJAR & Frequency & Percent \\
\hline Auditori & 12 & 21,1 \\
Auditori visual & 2 & 3,5 \\
Kinestetik & 27 & 47,4 \\
Kinestetik auditori & 7 & 12,3 \\
Kinestetik visual & 3 & 5,3 \\
Visual & 6 & 10,5 \\
Total & 57 & 100,0 \\
\hline
\end{tabular}

Gambaran data hasil belajar pendidikan jasmani murid SD Inpres No. 33 Sumpang Binangae Kab. Barru dapat dilihat pada tabel dibawah ini:

Tabel 2. Distribusi frekuensi dan kualifikasi hasil belajar pendidikan jasmani murid SD Inpres No. 33 Sumpang Binangae Kab. Barru.

\begin{tabular}{cccc}
\hline $\begin{array}{c}\text { Hasil } \\
\text { belajar }\end{array}$ & Frekuensi & Kualifikasi & Percent \\
\hline $80-100$ & 6 & $\begin{array}{c}\text { Sangat } \\
\text { tinggi }\end{array}$ & 10,5 \\
$60-79$ & 51 & $\begin{array}{c}\text { Tinggi } \\
\text { Sedang }\end{array}$ & 89,5 \\
$40-59$ & - & $\begin{array}{c}\text { Rendah } \\
\text { Sangat } \\
20-39\end{array}$ & - \\
$0-19$ & - & \begin{tabular}{c} 
rendah \\
\hline
\end{tabular} \\
\hline
\end{tabular}

Uji hipotesis hubungan gaya belajar dengan hasil belajar pendidikan jasmani murid Sekolah Dasar dapat dilihat pada tabel dibawah ini:

Tabel 3. Hasil analisis hubungan gaya belajar dengan hasil belajar pendidikan jasmani murid SD Inpres No.33 Sumpang Binangae Kab. Barru

\begin{tabular}{lcccc}
\hline \multicolumn{4}{c}{ Hasil belajar pendidikan jasmani } \\
\hline Gaya belajar & F & $\%$ & $\begin{array}{c}\text { Countingency } \\
\text { coefficient }\end{array}$ \\
\cline { 3 - 5 } & & & sig & value \\
\hline Auditori & 12 & 21, & & \\
Auditori visual & 2 & 3,5 & & \\
Kinestetik & 27 & 47, & & \\
Kinestetik & 7 & 12, & 0,02 & 0,893 \\
auditori & & 3 & 8 & \\
Kinestetik & 3 & 5,3 & & \\
visual & & 10, & & \\
Visual & 6 & 5 & & \\
\hline
\end{tabular}

Berdasarkan tabel 3.tingkat signifikan atau probabilitasnya lebih kecil dari pada $0,05 \quad(0,028<0,05)$, maka disimpulkan bahwa ada hubungan yang signifikan antara gaya belajar dengan hasil belajar pendidikan jasmani murid sekolah dasar SD Inpres No. 33 Sumpang Binangae Kab. Barru.

Uji hipotesis peluang munculnya masing-masing gaya belajar pada murid SD Inpres No.33 Sumpang Binangae Kab. Barru dapat dilihat pada tabel dibawah ini: 
Tabel 4. Analisis peluang munculnya masing-masing gaya belajar gaya belajar murid SD Inpres No.33 Sumpang Binangae Kab. Barru

\begin{tabular}{lcccc}
\hline \multicolumn{1}{c}{ Gaya belajar } & F & $\%$ & $\begin{array}{c}\text { Chi- } \\
\text { Square }\end{array}$ & df \\
\hline Auditori & 12 & 21,1 & & \\
Auditori visual & 2 & 3,5 & & \\
Kinestetik & 27 & 47,4 & 45,211 & 5 \\
Kinestetik auditori & 7 & 12,3 & & \\
Kinestetik visual & 3 & 5,3 & & \\
Visual & 6 & 10,5 & & \\
\hline
\end{tabular}

Dari tabel 4. tersebut diatas dapat dilihat bahwa nilai chi square hitung $(\mathrm{X}$ hitung): 45,211 sedangkan chi square tabel (X tabel) dengan tingkat kepercayaan 0,05 dan $\mathrm{dk}=\mathrm{k}-1=6-1=5$, diperoleh nilai 11,070. Dengan demikian disimpulkan bahwa $X$ hitung > X tabel $(45,211>11,070)$ yang artinya Ho ditolak dan $\mathrm{H} 1$ diterim atau dengan kata lain peluang munculnya masing-masing gaya belajar tidak sama pada murid, khususnya di SD Inpres No.33 Sumpang Binangae Kab. Barru.

Setiap masyarakat bermacam-macam peradabannya dengan latar belakang adat istiadat yang berbeda-beda, agama, hukum, bahasa, permainan dan sebagainya. "perkembangan menyebabkan terjadinya diferensiasi yang menghasil tabiat manusia yang beragam (Fajar Mugo Raharjo, Agung Nugroho, \& Ahmad Al Munawar, 2020). Timbulnya deferensiasi bukan disebabkan pembawaan, tetapi melalui proses dengan sejarah perkembangan" (A.M Agussalim, 2005: 41).

Hasil penelitian menunjukkan bahwamurid dengan gaya belajar visual, auditori dan kinestetik tuntas dalam hasil belajar pendidikan jasmani dan murid yang bergaya belajar kinestetik lebih unggul dari gaya belajar yang lain dalam hasil belajar pendidikan jasmani dan "Dalam mendidik dan mengajar, para guru tentunya memerlukan pengetahuan dan kesabaran yang sangat besar. Bahkan diperlukan cara berpikir yang positif dan kreatif, agar siswa mudah belajar sehingga bakat, kecerdasan, dan prestasinya bisa meningkat dengan baik” (Rudiana, 2012: 121). M. Nur Ghufron \& Rini Risnawati (2013), mengatakan bahwa "pada prinsipnya gaya belajar merupakan bagian integral dalam siklus belajar aktif”. Maka dari itu amatlah wajar jika gaya belajar merupakan salah satu faktor yang tidak boleh disepelehkan oleh seorang guru dalam proses pembelajaran.

Berdasarkan uraian diatas dan dengan teori-teori yang mendukung dapat disimpulkan bahwa ada hubungan antara gaya belajar dengan hasil belajar, khususnya hasil belajar pendidikan jasmani murid SD Inpres No.33 Sumpang Binangae Kab. Barru 
2. Hasil analisis peluang munculnya masingmasing gaya belajar murid SD Inpres No.33 Sumpang Binangae Kab. Barru

Hasil penelitian ini menunjukkan bahwa peluang munculnya masing-masing gaya belajar tidak sama yang artinya hipotesis diterima. Sehubungan dengan penerimaan hipotesis tersebut maka dapat dijelaskan bahwa setiap murid memiliki gayanya tersendiri dalam belajar, dan setiap murid memiliki kelebihan dan kekurangannya masing-masing (Wiyani, Novan Ardy, 2013). Dari hipotesis penelitian ini, dapat dilihat bahwa gaya belajar kinestetik memiliki peluang muncul yang lebih tinggi dibandingkan dengan gaya belajar yang lain. Dengan pertimbangan bahwa gaya belajar kinestetik pada hakekatnya sama dengan dunia anak (bermain) yakni berpusat pada gerak (Rahyubi, Heri, 2012). Dunia anak adalah bermain dan setiap daerah memiliki keberagaman tersendiri baik bahasa, adat, hukum dan terkhusus dari segi bermain.

Berdasarkan uraian tersebut dan dengan teori-teori yang mendukung dapat disimpulkan bahwa peluang munculnya masing-,masing gaya belajar tidak sama pada murid, khususnya di SD Inpres No.33 Sumpang Binangae Kab. Barru

\section{KESIMPULAN}

Berdasarkan hasil penelitian diatas dapat disimpulkan bahwa Ada hubungan gaya belajar dengan hasil belajar pendidikan jasmani murid SD Inpres No.33 Sumpang Binangae Kabupaten Barru. Peluang munculnya masing-masing gaya belajar Tidak sama pada murid, khususnya di SD Inpres No.33 Sumpang Binangae Kabupaten Barru.

\section{DAFTAR PUSTAKA}

Agussalim, A.M. (2005). Ilmu Sosial Budaya Dasar. Makassar: Badan Penerbit UNM Makassar.

Devi Catur Winata, Muhammad Fahmi, \& Andi Nur Abady. (2020). Influence of Play Approach Against Sprint Learning Outcomes. Jurnal Pendidikan Jasmani (JPJ), 1(1), 813.

https://doi.org/10.55081/jpj.v1i1.109

Fajar Mugo Raharjo, Agung Nugroho, \& Ahmad Al Munawar. (2020). The Influence of Reciprocal Teaching Style on Volleyball Smash Learning Outcomes. Jurnal Pendidikan Jasmani ～(JPJ), 1(1), 14-18. https://doi.org/10.55081/jpj.v1i1.105

Ghufron, M. Nur., dan Rini Risnawati. (2013). Gaya Belajar. Yogyakarta: Pustaka Pelajar.

Keliat, P., Karo-Karo, A. A. P., \& Muhammad Syaleh. (2020). The Effect of Reciprocal Teaching Style on Pencak Silat Side Kick Learning Outcomes. Jurnal

Pendidikan 
Workout From Home Sebagai Aktivitas Mahasiswa Menjaga Kebugaran Jasmani

(Studi Fenomenologi Aktivitas Mahasiswa Ilkor UMBY dalam Menjaga Imunitas Menghadapi Pandemi COVID-19)

Jasmani $\quad(J P J), 1(1), \quad 19-23$. https://doi.org/10.55081/jpj.v1i1.106

Nazarudin,, Tomasouw, J., Zainuri, A., Rahayu, E.T., Karo Karo, A.A.P. (2020). Student mental health character in covid-19 situation. International Journal of Pharmaceutical Research,12(4). 3547-3553.

DOI: https://doi.org/10.31838/ijpr/2020.12 .04 .485

Rahyubi, Heri. (2012). Teori-Teori Belajar dan Aplikasi Pembelajaran Motorik Deskripsi dan Tinjauan Kritis. Bandung: Nusa Media.

Rudiana. (2012). 9 Karakter Guru Menyenangkan Berbasis Ramah Otak. Bandung: Smile's Indonesia Instute.

Sadri, M., Yuliandari, R.N., Sari, L.P., Cahyadi, A., Maolinda, W. (2020). Prenatal education of personal human development in COVID-19 pandemic. International Journal of Pharmaceutical Research, 12(4), 3508-3515, DOI: https://doi.org/10.31838/ijpr/2020.12 .04 .479

Sugiyono. (2012). Statistika untuk Penelitian. Bandung: Alfabeta.

Sukardi. (2012). Metodelogi Penelitian Pendidikan. Jakarta: Bumi Aksara.

Wiyani, Novan Ardy. (2013). Membumingkan Pendidikan Karakter di SD. Jogjakarta: Ar-Ruzz Media. 